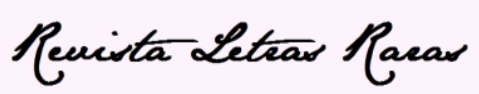

ISSN: $2317-2347$ - v. 8, n. 2 (2019)

\title{
Além da subversão
}

David Araújo de Carvalho*

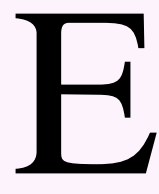

mílio era observador, zeloso por natureza. Não era retraído, mas reservado. Cada detalhe era uma informação nova. Uma análise sobre com quem estava se metendo. Dado seu nascimento em 1969, seu pai, apaixonado pelos desfiles do sete de setembro, o batizou dando-lhe o nome do então comandante do III Exército, Emílio. O nome não caiu bem para seus amigos. Uma criança, uma criança receber o nome de um ditador? Como seria o futuro do pequeno, um reacionário, filhote da ditadura? Torturador por excelência? O exército espalhado, o AI-5 em vigência, o linha dura do Médici matando nossos camaradas e você coloca o nome desse garoto de Emílio? Você ficou louco, não tem medo de ser justiçado? Veja o que fizeram com o embaixador, aquele porco emissário dos imperialistas. Se não libertarem os nossos camaradas, que ele vá conversar com o capeta. Se é que existe céu e inferno, meu camarada. Essas falas sempre ecoavam pelos ouvidos de Aragão. Não queria queixa contra esses elementos subversivos. Os achava muito radicais. De uma, chegou a reclamar com o líder do sindicato que estava ligado ao Partidão.

- Vocês piraram? Ficaram loucos... Até quando pretendem seguir com essa merda?

Você não vê que estão matando nossos jovens? De onde já se viu, caramarada? De onde já se viu... Recrutar garotos para matar nossos militares?

- Fica com a boca fechada, se não quiser acordar com o Lamarca na tua casa. Eles não estão sozinhos, estão recebendo treinamento. Nosso capitão está dando todo o preparo para eles não serem ovelhas. Que foi? Vai dar pra trás agora? Fica de olho, a sorte não bate à porta duas vezes.

Quantas vezes já não fora alertado de ficar com a boca fechada. Aragão era um iludido, desconhecedor do espírito humano. A sagacidade e aspereza vermelha não entravam em suas veias, nem se fazia crer que seus amigos iriam fazer algo consigo e com o filho. Porém, temendo pela incerteza, mudou os planos. Era pai agora, e não podia continuar no incerto. Dirigiu-se a um quartel do exército, relatou os fatos e pedira ajuda para proteção do filho. Não demora, temendo algo pior, os responsáveis pelo batalhão ficaram com a criança. 


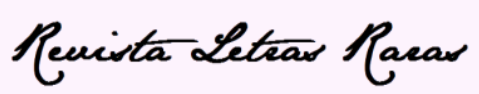

ISSN: 2317-2347 - v. 8, n. 2 (2019)

Não havia seis meses de nascido, e ele já estava sob a custódia dos reacionários. A morte do pai não era normal de se relatar pelos os agentes do DOPS. O rosto desfigurado com tanta coronhada marcava a brutalidade vermelha. As orelhas foram arrancadas e colocadas na boca de Aragão. Os olhos, estes foram queimados com o cano de um fuzil, seus testículos estourados com chutes e golpes de martelo. Fezes e urina cobriam suas pernas. A calça pesava de sangue e merda. Esse era só mais um para a conta dos milicos pelo Tribunal Revolucionário. Nos registros feitos, ainda havia o tiro de misericórdia.

- Então, camarada? Resolvido?

- Resolvido o quê?

- Como o quê, poxa? Tu justiçou o cara?

- Sim. Deixei um presente para os milicos... O Aragão era um dos nossos, a impressa não vai desconfiar. Filho da puta!

- Que bom. Agora, faça o mesmo com a vagabunda da sua mãe. No comitê do partido, estão dizendo que ela vai sair do Rio para o Nordeste. Apaga logo essa vagabunda. Ou você sairá do Partido. Às vezes, penso que é duro... Mas lembre, a causa é justa, camarada.

- Mas, camarada. Não pode outro em meu lugar?

- Ou você mata a vagabunda ou o camarada será justiçado. Ficou claro? Ficou claro, camarada?

$-\operatorname{Sim}$.

A linha vermelha que dividia o mundo econômico e político fazia parte do território brasileiro. O país estava centrado em três problemas. Um deles, bem pior, era o de desenvolvimento, tocar a economia pra frente, gerar empregos, baixar a inflação. Por momentos de ouro, Delfin Neto se tornara a menina dos olhos de ouro do país. Médici era erguido e abraçado pela população. O mais duro dos militares era agarrado pelo alvoroço popular. Outro problema era manter a economia sob a normalidade urbana. A guerrilha estava em todo lugar. $\mathrm{O}$ que pesava na canetada do presidente era combater "os filhos da mãe gentil". Garotos apaixonados e cegos pelo ideal socialista eram combatidos pelos soldados. Mortos pela causa. O último estava no por vir. No futuro, na abertura política e nas controversas. Sabiam que seriam vilões da história. Ditadores. Mas esse dia pela infelicidade da nação estava próximo. 


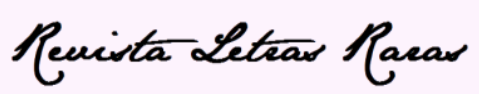

ISSN: 2317-2347 - v. 8, n. 2 (2019)

Emílio, mais uma vez, presenciava os fatos serem distorcidos. O país estava o inverso, de cabeça para baixo. Viu Antônio puxar a arma e começar a recrutar os apaixonados pelo marxismo. Ação Libertadora Nacional se tornara um símbolo de resistência e democracia. Sentiu na pele o Manual de Marighela - quando isso? No relato da morte de seu pai. Agora, no curso de Direito, alunos sendo parte de assembleias, partidos e movimentos. Professores com armas nas mãos escrevendo no quadro frases típicas de Assembleias Estudantis - Tem arma maior que a ditadura cultural? Morte aos porcos capitalistas! Morte as reacionários! Maria era uma cadela. Jesus era o porco. Continuamente, com tambores e o megafone, o sindicato novamente entrara na sala interrompendo a aula.

- Tô de saco cheio de tanta greve.

- Oh, pessoal! Oh, pessoal! - gritava uma estudante de História, líder feminista, com os seios à mostra - Olha aqui o filhote da ditadura. Defensor de torturador.

— Tem ditadura pior do que conviver com vocês?

- Oh, galera... Tô sendo agredida por esse machista e racista. Machistas, fascistas, não passarão! Machistas, fascistas, não passarão! - em pouco tempo, toda a assembleia repetia.

O eco se espalhava em aglomeração por todo campus. Frases soltas, sem conexões com a realidade, produziam o intelectual da pós-modernidade. Já no ônibus, pela janela, Emílio via o contraste. Garotos, idosos, adultos, pessoas de todas as idades carregavam faixas com os dizeres "Ustra Vive! Salve 31 de março de 1964! Pela volta dos botões dourados!" "Um, dois, três, quatro, cinco mil, queremos os militares no comando do Brasil!’. Como de costume, ainda observando pela janela do ônibus, o filhote da ditatura pensava em voz alta lembrando a cena da universidade e as cadelas no cio com os peitos à mostra.

- Como podem acreditar em tamanha baboseira, não veem o exemplo da Coreia? Não entendem o banho vermelho?

Tão perdido, não dera conta quando fora interrompido pelo passageiro ao lado, parecia ter pouco mais de 60 anos, que apenas disse:

- Dá certo sim, meu jovem... O povo é que não sabe passar fome. 